\title{
ヒステレシス永久歪について
}
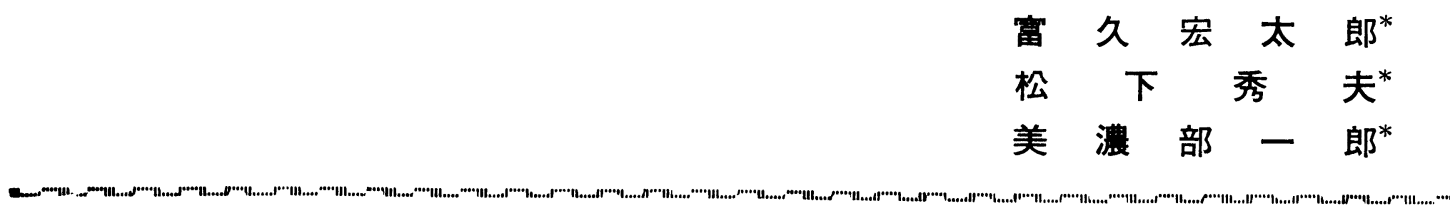

\section{1. 永久歪、ヒステレシスとは}

理想的な弾性体と異り、ゴム、プラスチックスでは外 力を加えて変形させた場合、外力を除いても实全に原形 状に戻らず、常に変形は不可逆で永久変形が残る。この 様な現象はこの様な物質が通常の条件では弾性だけでな く塑性変形も示すためと考えられる。Hysteresis，永久 歪、Creep, 応力緩和等の現象はこのことに起因すると 考えるのが妥当である。従つて以下これらの観点から永 久歪、hysteresis について述べる。

\section{1 永 久 昰}

ゴムに外力（伸長、王縮、剪断）を加えて後荷重を除 去すると歪の大部分は急速に回復するがある程度の歪を 残して平衡に達する。この歪を“永久歪”と呼んでい る。一般にはこの歪は望性流動として考えられているが 弾性変形との組合として考えなければならない。

Treloar1) はゴムを延伸すると低エネルギーの凝集連 鎖が生じ、これが歪の回復を妨げるとし、又長鎖の分子 間の Van der Waals 力も回復の速度、永久歪に等与して いると考えている。Andrew2) 等は分子理諭を用いて高 温度での加硫ゴムの延伸について研究し、永久歪は網目 状構造の酸化による cross-link, 及び網目状棈造の酸化 分解に原因するとしている。Gehman ${ }^{3}$ ) 文高伸長、長時 間の試験では明らかに棈造上に大きい変化が認められ棈 造の単位が大きい程絬合の破壤も大きくなり外力を除い ても構造の変化が回復しないと考光ている。Mullins4) は永久歪を不可逆な塑性流動の結果として考え、延伸時 に生ずる回復を好げようとする結合力と促進させる䓡的 な力との間の平衡関係によつて決るとのべている。以上 の如く永久歪は外打による分子棈造の変化によるもので 完全弾性体では見られぬ現象である。

\subsection{Hysteresis}

ゴムに機械的な変形を与える場合歪力歪曲線は第 1 汹 の如くなる。この曲線を hysteresis-loop と呼び、曲 線 $\mathrm{ABC}$ の下の面積はゴムに与えられた仕事最に当り hysteresis loss は loop の面積 (ABCDE) と曲線 ABC の下の面積との此で表される。ここで $\mathrm{AE}$ は永久昰に 相当し hysteresis に関係があることが分る。Hysteresis loss はゴムに対してなされた仕事量に相当し唂エネル ギーとなつて繰返し変型が一えられたときゴムの温度上 昇となる。

Hysteresis の現象は内部摩擦によつて生ずると考学 られているが事実振巾の小さい範团はで hysteresis loss は小さく液体の摩繁の場合と同じく変形速度に比例する

* 東洋ゴム工業柇式会社技術研究所

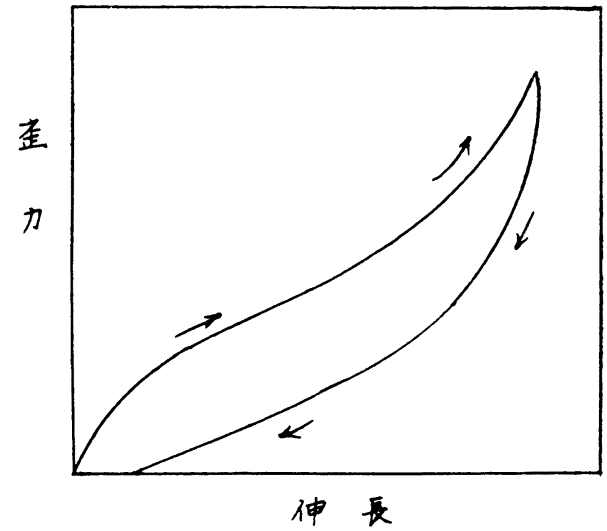

第 1 汹 静的ヒステレシスループ

と考えられる。5) 然し hysteresis は内部摩擦にみらて る流動 塑性に基く機械的な平衡よりのずれの他に更に 熱的な平衡のずれ、綰晶化等に基く相平衡のずれについ ても洘えねばならない。例えば純ゴム配合の加硫物の高 延伸では絬昆化がみられ内部エネルギ一を減少させ hysteresis に影绵する。

\section{3 模型的な考察}

ゴム、プラスチックス等の弾性的举動を理解するため

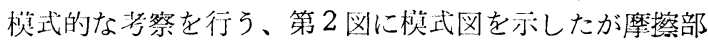
をバネ、粘州蔀を dash-pot で表している゚8) A図はバ ネと dashpot が平行に列んだものでゴムの振動現象を 解勫出来る。 $\mathrm{B}$ 汹は Maxwell の忍力綏和説に基いて得

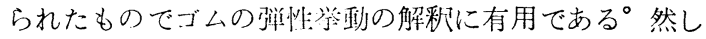
一般には而に系は教雑で $\mathrm{G}$ 区は長時間の creep, 忘力緩 和を就明するのによく、d 図はMaxwell の図を平行に 網目状として用い一般的な場合の解釈に用いる。勿論こ れらもある制限内で訪明可能であるが複雑な分子構造を 規定することは出来ない。

加硫ゴムの動力学的模型として第 3 図の様な模型があ る。9)これは $\mathrm{A}, \mathrm{B}, \mathrm{C}$ の3つの阷に分れ、Aは純弾性に 基く杪型で少怢係数をもつ理想的な弾性体を示す部分で ある。B群沈抄性係数 $\mathrm{E}_{\eta \mathrm{i}}$ のバネと粘性係 $\eta_{\mathrm{i}}$ の dashpot が篮裂されたVoigt の模式の集りで余効効果を示 し周波数依存性をもつ。C洋は $\mathrm{CE}_{\mathrm{Si}}$ のバネと歪力が $\mathrm{S}_{\mathrm{i}}$ になると始める内部摩擦機蒋を並置した模式の集 りで hysteresis を示す振け依存性の部分である。更に 高温度、長时間の変形では永久歪が相当大きく表れるた め純粘性の部分Dを加えている。これらを基にして一般 の加硫ゴムの基礎方程式として次の様なものが示されて いる。 


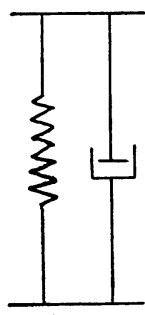

A：平行型

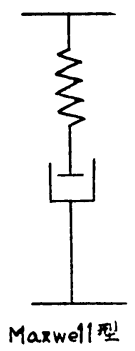

第 2 汹
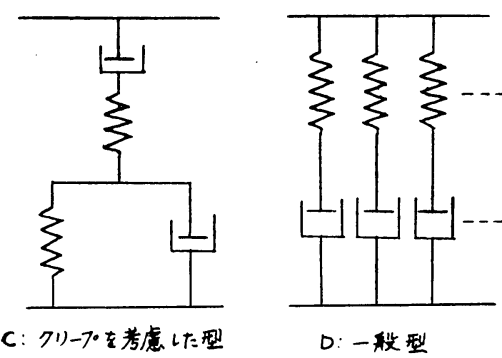

D: 一般型

摩擦力と速度の間の比例常数 $[$ dyne $/ \mathrm{cm}$ - sec], s はバネの強さ [dyne $/ \mathrm{cm}], \mathrm{p}_{0}$

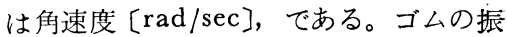
動試験では自由振動の中振動に与えられ る振動エネルギーの成分を以て動的反撥 弾性を定義しているがこの様にすれば 1 回の振動で熱に変る振動エネルギー成分 は動的反撥性で与えられる。振動エネル ギは振やの 2 乘に比例 するから右 㸚から

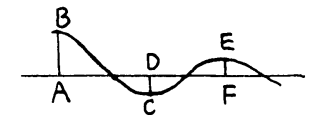

動的反撥率 $=\mathrm{EF}^{2} / \overline{\mathrm{AB}}^{2}=\mathrm{R} \cdots$

$$
\varepsilon(\mathrm{t})={ }_{\mathrm{E}}^{1} \sigma(\mathrm{t})+\int_{0}^{\infty} \Phi(\nu) \int_{-\infty}^{\mathrm{t}} \mathrm{e}^{-\nu(\mathrm{t}-\tau) \sigma(\tau) \cdot \sigma \tau \cdot \sigma \nu}
$$$$
+\int_{0}^{\sigma / 2} \varphi(\mathrm{s})\{\sigma(\tau)-2 \mathrm{~s}\} \mathrm{ds}+\int_{-\infty}^{\mathrm{t}} 1 \sigma(\tau) \mathrm{d} \tau \cdots
$$
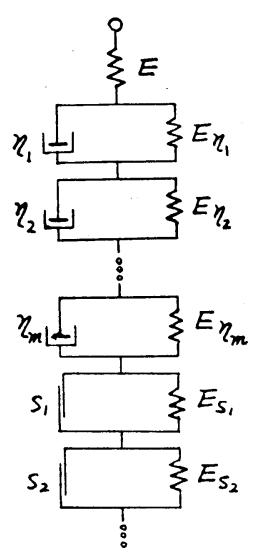

右辺の第 1 項は純弾性特性を表 す項、第 $2 、 3 、 4$ 項は夫々余効効 果、特性、hysteresis 特性、純粘 性特性を示す項である。

\section{4 種々の条件に於ける hysteresis ${ }^{8}$ )}

ゴム状物質の hysteresis loss 評価する場合次の様な条件で分類 する。

i ) Low speedの歪力一歪環線

ii) Impact resilience

iii) 白由振動

iv）共振を伴う強制振動

v ）非共振の強制振動

i ) Low speed stress strain loop 第 1 困に示した様に伸長 による hysteresis loopの面積は 熱に贸りうる弾性エネルギーに比 例する。この loop.の大きさ、形 状より hysteresis の大小、creep, 第3図力学的模式 回復 creep, 応力綏和等を就価 出来る。

ii Impact resilience ゴムの反撥弾性は球又は 振子を用いて行らが、これまでは初期の衝慗エネルギー の衝揧後得られる反撥エネルギーに対する百分率で衣す のが普通である。振動試験と異り減衰振動の半周期とし てしか表れない。

iii）自由振動或る質量をゴムで文持して質量に自 然減衰的に振動させる場合振動の継綎に於ける振巾の低 下、周期の逯昰として hysteresis が表れる。この時の 運動方程式は

$$
\begin{aligned}
& \mathrm{m} \cdot \frac{\mathrm{d}^{2} \mathrm{x}}{\mathrm{df}^{2}}+\mathrm{d} \frac{\mathrm{dx}}{\mathrm{df}}+\mathrm{s} \mathrm{x}=0 \\
& \text { この解 } \quad \mathrm{x}=\mathrm{x} \mathrm{e}^{-\frac{\mathrm{bt}}{2 \mathrm{~m}}} \cos \mathrm{p}_{0} \mathrm{t}
\end{aligned}
$$

$\mathrm{p}_{0}=\sqrt{ } 4 \mathrm{~m} \mathrm{~s}-\mathrm{b}^{2} / 2 \mathrm{~m}$

critical damping は $\quad \mathrm{bc}=2 \mathrm{~m} \sqrt{\mathrm{s} / \mathrm{m}} \cdots(1.5)$ ここでmは質量 $[\mathrm{g}], \mathrm{x}$ は変位 $[\mathrm{cm}], \mathrm{t}$ は時間 $[\mathrm{sec}], \mathrm{b}$ は

$$
\begin{aligned}
& \text { Dynamic Resilience }=\mathrm{EF}^{2} / \mathrm{AB}=\mathrm{R} \cdots(1 \\
& \text { (1.3)より } \mathrm{R}=\mathrm{EF} / \mathrm{AB}=\mathrm{e}-\frac{\pi \mathrm{b}}{\mathrm{mp} 0} \quad\left(\mathrm{t}=2 \pi / \mathrm{p}_{0}\right)
\end{aligned}
$$

従つて $\quad \mathrm{R}=\mathrm{e}^{-\frac{2 \pi \mathrm{b}}{\mathrm{mp_{0 }}}}=\mathrm{e}^{-\pi \mathrm{P}_{0} \mathrm{~b} / \mathrm{s}}$

iv) 強制振動 正弦波的な起動力 F cospt の強制振 動をうける場合の運動方程式は

$$
\mathrm{m} \frac{\mathrm{d}^{2} \mathrm{x}}{\mathrm{dt}^{2}}+\mathrm{b} \frac{\mathrm{dx}}{\mathrm{d} t}+\mathrm{sx}=\mathrm{F} \cos \mathrm{pt}
$$

定常状態法を用いて

$$
\begin{gathered}
\mathrm{x}=\frac{\mathrm{F}}{\sqrt{\left(\mathrm{s}-\mathrm{mp} \mathrm{p}^{2}\right)^{2}+\mathrm{b}^{2} \mathrm{p}^{2}} \cos (\mathrm{pt}-\phi)} \\
\text { 位相角 } \phi=\tan ^{-\mathrm{T}}\left(\frac{\mathrm{bp}}{\mathrm{s}-\mathrm{mp^{2 }}}\right)
\end{gathered}
$$

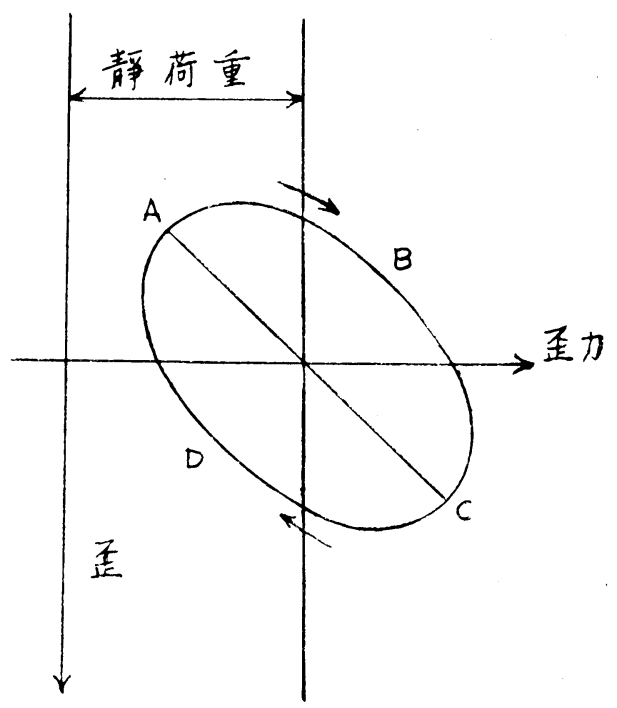

第 4 図振動の場合のヒステレシスループ

第4眓の様な動的な歪力-歪の系の図によつて隇衰項 $\mathrm{b} \frac{\mathrm{dx}}{\mathrm{dt}}$ が衣される。この hysteresis loop は惰円で表されそ の面積は 1 回の系の消失するエネルギ一損失に相当す る共振系では(1.10)式から $\mathrm{x}=\mathrm{x}_{\max }$ で

$$
\mathrm{p}^{2}=\stackrel{\mathrm{s}}{\mathrm{m}}-\left(\frac{\mathrm{b}}{2 \mathrm{~m}}\right)
$$


第一近似として $\mathrm{s}=\mathrm{m} \mathrm{p}_{0}{ }^{2}, \mathrm{~b}=\frac{\mathrm{F}}{\mathrm{p}_{0} \mathrm{x}_{\max }}$

ここに $\mathrm{s}, \mathrm{b}$, は共振の振巾、振動数、質量、起電力によ つて決る。実験的には bp は振動数の変化に伴い略々一 定で $\mathrm{s}$ も振動数には無関係である。従つて共振系では振 巾、dynamic resilience (動的反撥率) は振動数には無 関係とみられる。

交流理論を用いてゴムの損失角 $(\delta)$ は10)

$\tan \delta=\mathrm{bp}_{0} / \mathrm{s}$

ゴム形状一定の場合 $\mathrm{s}$ 及び $\mathrm{b}$ は試料の大きさに無関係に おくことが出来、11)従つて弾性係数は $\mathrm{E} は$

$$
\begin{aligned}
& \mathrm{E}=\mathrm{s}\left(\frac{\mathrm{h}}{\mathrm{a}}\right)=\mathrm{sq} \\
& \eta=\mathrm{b}\left(\frac{\mathrm{h}}{\mathrm{A}}\right)=\mathrm{bq} \quad \mathrm{q}=\frac{\mathrm{h}}{\mathrm{A}}
\end{aligned}
$$

$\mathrm{h}$ 試片の高さ、A は陚片の自由面積、 $\eta$ は内部摩擦係 数、qは形状率、とすると（1.10)、(1.11) は

$$
\begin{aligned}
& \mathrm{x}=\mathrm{E} \mathrm{q} \cos (\mathrm{pt}-\phi) \\
& \mathrm{x}=\sqrt{ }(\mathrm{E}-\mathrm{mqp})^{2}+\eta 2 \mathrm{p}^{2} \\
& \tan \phi=\frac{\eta \mathrm{p}}{\mathrm{E}-\mathrm{m} \mathrm{q} \mathrm{p}^{2}}
\end{aligned}
$$

剪断振動の場合も同様に扱うことが出来るが $\eta$ 及び風 性率 $\mathrm{G}$ が用いられこの場合試料の大きさ、形状に無関係 である。

\section{5 的的条件に於ける温度上年}

hysteresis に基くエネルギ一損失は熱エネルギーとな りゴムの温度上昇となる。この場合内部摩擦と弾性係数 が決定的な要紊と考えられ12）振動を考えた場合、熱工 ネルギー量は hysteresisにより考えることが出来る。

振動によつて発生する熱量は $\int \mathrm{bxdx}$ の系全体につい て求めるとよ(13)。即ち

$$
\mathrm{H}_{\mathrm{x}}=\frac{\pi \mathrm{p} \eta \mathrm{x}^{2}}{\mathrm{q}}
$$

又は $\mathrm{H}_{\mathrm{F}}=\mathrm{F}^{-\pi \mathrm{q} p \eta \mathrm{F}}$

$\mathrm{x}$ は振巾、 $\mathrm{F}$ は压縮力の最大值、 $\mathrm{Hx}$ は一定振巾の振 動、 $\mathrm{H}_{\mathrm{F}}$ は一定荷重の振動に於ける系の発熱量である。

これらの式は一般の圧縮振動の場合に適用出来る。夕 イヤの場合は一般に振動数 $\mathrm{p}$ は共振振動数 $\mathrm{p}_{0}=\sqrt{\mathrm{E} / \mathrm{mq}}$ より小さく

$$
\mathrm{Hx}=\frac{\pi \mathrm{p} \eta \mathrm{x}^{2}}{\mathrm{q}}
$$

$$
\text { 又は } \mathrm{H}_{\mathrm{F}}=\frac{\pi \mathrm{pq} \eta \mathrm{F}^{2}}{\mathrm{E}^{2}}
$$

$\mathrm{p} \eta / \mathrm{E}$ は極めて小さいから dynamic resilience $\mathrm{R}$ (動 的反撥率）は

$$
\begin{aligned}
& \mathrm{R}=\mathrm{e}^{-} \pi_{\mathrm{p}} \eta / \mathrm{E}=1-2 \pi_{\mathrm{p}} \eta / \mathrm{E} \\
& \text { 又は } \quad \pi \mathrm{p} \eta=\frac{\mathrm{E}}{2} \\
& \mathrm{H}_{\mathrm{x}}, \mathrm{H}_{\mathrm{F}} \text { は夫々 } \mathrm{R} \text { より求める事 } \\
& \mathrm{H}_{\mathrm{x}}=\frac{1}{2 \mathrm{q}}(1-\mathrm{R}) \mathrm{Ex}^{2} \\
& \mathrm{H}_{\mathrm{F}}=\frac{\mathrm{q}}{2}(1-\mathrm{R}) \frac{\mathrm{F} 2}{\mathrm{E}}
\end{aligned}
$$

$\mathrm{H}_{\mathrm{x}}, \mathrm{H}_{\mathrm{F}}$ は夫々 $\mathrm{R}$ より求める事が出来る。即ち、

一定振巾の場合は内部摩擦にのみ比例し、 $\eta_{1} / \eta_{2}$ 又は
$\left(1-\mathrm{R}_{1}\right) \mathrm{E}_{1} /\left(1-\mathrm{R}_{2}\right) \mathrm{E}_{2}$ の比によつて求められるが、一定 エネルギーの場合は弾性係数にも係関する。即ち $\eta_{1} \mathrm{E}_{2}{ }^{2}$ $/ \eta_{2} \mathrm{E}_{1} 2$ 又は $\left(1-\mathrm{R}_{1}\right) \mathrm{E}_{2} /\left(1-\mathrm{R}_{2}\right) \mathrm{E}_{1}$ によつて求められ る。

静荷重を加えた場合の温度上昇は発生した熱量と熱損 失量との平衝によつて表せる。一定振巾の場合の温度上 昇 $\Delta T_{x}$, 一定荷重の場合の温度上昇 $\Delta T_{F}$ は

$$
\begin{aligned}
& \Delta \mathrm{Tx} \infty \eta / \lambda \\
& \Delta \mathrm{T}_{\mathrm{F}} \infty \eta \mathrm{x}^{2} / \lambda
\end{aligned}
$$

従つて温度上昇に大きく寄与するのは動的粘性である内 部摩擦 $\eta$ 及び熱損失入である事が示される。

\section{6 振動特性と永久歪 Hyteresis}

永久歪は主として分子槛造のうり、徒つて内部粘性に 関係し、hysteresis は内部摩擦によつて生ずると考えら れている。この様な性質は動的条件では温度、振動数等 によつて影響される事が、推察されるが、ここでは内部 摩擦を主として考察してみる。

i ) 振動数依你性 内部摩撜係数は近似的に振動数 に反比例する。4) 粘性係数と同様内部摩擦係数は振動数 と大体双曲線関係を有し、振動摩捥は振動数の増大に伴 い隇少する。双曲線よりのずれがみられるのは、振動数 の大きい場合に発熱量が大きいため内部摩擦が加重し減 少するためと思はれる。この関係は第 5 図の反蜅率と振

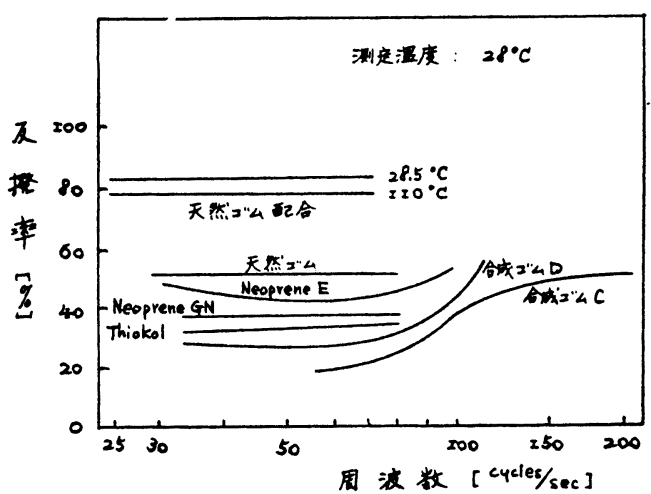

第 5 渓 反撜性の周波数特性

動数の関係にもみられる。(1.23)式で $\mathrm{p} \eta / \mathrm{E}$ が振動数に 拘らず一定の場合、動的反撥率 Rも一定でなければなら ないが、合成ゴムのあるものや、neoprene E では著し く上昇しているのが認められる。

ii）温度依存性ゴムを延伸する場合、温度上昇と 共に弾性係数は增大するが、これは配列分子の熱エネル ギーが增加し、分子を元の無秩序な配列に回復させる力 が增加するためと思はれる。然し振巾の小さいものでは これらを余り考庶する必要はない。14) 第6 図に温度上 昇に伴う反撥率の変化を示したが、30 $\mathrm{C}$ 以上では温度 上昇に伴い殆んど直線的に增大している。この点では少 くともゴんに急激な転移が生じるものと思はれ、温度の 低下に伴い反撥率は急激に減少する。低温高摩擦部では 理論曲線 $\eta=\mathrm{A}, \mathrm{CB}_{1} / \mathrm{T}$ 上にあり、高温低摩擦部では $\eta=$ $\mathrm{A}_{2} \mathrm{C}-\mathrm{B} 2 / \mathrm{T}$ 上にある。これらの曲線では明らかに転移点 を示し、 $\eta^{-1} / \mathrm{T}$ の折点が第二次結合の破壞温度を与え、 


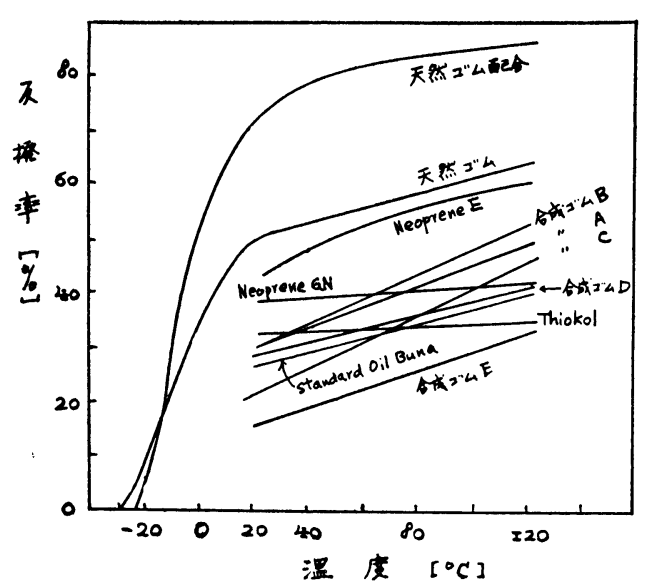

第6困 反撥性の温度特性

この点以上では分子の配列の変化に必要なポテンシャル の谷の高さが低下し、分子の一部に相対運動が生じ易く なるものと思はれる。

iii）結晶化 加硫ゴムの延伸時にみられる結晶化は 可逆で、伸長、温度に関係し、時間には無関係である。 この結晶化は非結晶部が安定な状態に到達しようとする 傾向に基くと考えられるが、非結昆部は不文定でも普通 の条件ではこの状態の変化には可成りの抵抗を示す。こ の転移は変形を与えると促進される。ゴム内部断面につ いて歪力では次の式で表せる。6)

$$
\tau=\left(\frac{\partial \mathrm{U}}{\partial \lambda}\right)_{\mathrm{T}}-\mathrm{T}\left(\begin{array}{c}
\partial \mathrm{S} \\
\partial \lambda
\end{array}\right)_{\mathrm{T}}
$$

$\lambda$ は伸長 [\%]、Tは絶対温度、Vは内部エネルギー、 $\mathrm{S}$ はエントロピーである。等温変形では(12.9)式で $\mathrm{T}\left(\begin{array}{l}\partial \mathrm{S} \\ \partial \lambda\end{array}\right)_{\mathrm{T}}$ は負である。純弾性体では $\left(\frac{\partial U}{\partial \lambda}\right)_{\mathrm{T}}=0$ であるが、一般 にこの項が負の場合は絬晶化の場合の様に歪力は非結晶 部の理諭值より小さい。この様な条件では結晶化は hysteresis の原因となり。事実一定伸長では結晶化は延伸 時より回復時の方が大きく、従つて歪力は回復時に小さ く、その結果 hysteresis loop が描かれる。

合成ゴムをみると、neoprene ではよく絬晶化し、同 時に hysteresis は天然ゴムの場合に可成り類似してい る。然し一般の合成高分子では絬晶化せず、カーボンブ ラックを充填しない場合 hysteresis を六してもそれは 永久歪が大きい部分を示すためと考えられている。カー ボンブラック配合の GR-S の場合も hysteresis を示し ているが高伸長時より低伸長時の場合の方が大きい。15) この場合結晶化はみられす望性流動を示すのみで、内部 摩擦が hysteresis の原因と思はれる。GR-S にみられ るこのつの現象は、重要な意味をもつと思われる。

\section{2. 永久歪、Hysteresis の測定法}

示久歪、殊に hysteresis を測定する場合、常にそれ がどの様な目的に用いられるかを考怒し、最も実用に即 した振動数、振巾、温度等の条件を啲択し、同時に測定 結果の表す意味を充分把撜する事が必要である。

\section{1 永久歪の測定法}

加硫ゴムに伸長、圧縮，又は剪断を加えて一定時間あ る条件で放置後荷重を除き回復しなかつた歪として永久 歪を測定するこの場合の回復 creep は加荷時間、荷重 の大きさによつて異るが、一般には平衝に達する時間は 極めて長いため、便宜上規格試験では荷重を除いてから 一定時間後の残留歪で指定される事が多い。16)

i ）永久伸 ゴムの静的な試験の一つとして用いら れ、片状又は環状の試片に一定荷重又は伸長を一定時間 一与えた後の残留伸を測定する方法が一般に用いられてい る。17)

第 1 表 永久伸試験規格例

\begin{tabular}{|c|c|c|c|}
\hline & 伸 & 伸長洔間 & $\begin{array}{l}\text { 荷重除去後測定 } \\
\text { 踔時間 }\end{array}$ \\
\hline $\begin{array}{l}\text { DVM 規格 } 76 \text { 号 } \\
\text { ASTMD 412-36T }\end{array}$ & 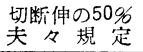 & 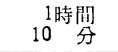 & $\begin{array}{c}5 \text { 分又は24時間 } \\
10 \text { 分 }\end{array}$ \\
\hline
\end{tabular}

DVM規格では環状試片を用いているが、この場合直 径 $25 \mathrm{~mm}$ の上下 2 個のローラ一間に試片をかけて、伸長 前に下方ローラーに小荷重をかけローラー中心距離 $30 \mathrm{~m}$ $\mathrm{m}$ となる荷重を求めておき、伸長後に緩めて残留伸を求 める際、この荷重を加えた状態で測定している。この 他、一定伸を与立所要の荷重の減少を求める。方法一定 伸長を繰り返し与えた後の残留伸を求める場合もある。 測定値は伸長の大きさ、温度、時間によつて大きく影響 される、

ii）圧縮歪 ゴムの配合の適否、加硫条件の決定等に も用いられるが、荷重の与え方につの型式がある。16). 18) 即ち一つは一定荷重（ASTM では厚み $1 / 2$ in, 直径: $1.129 \pm 0.001$ in の円柱形試片を用い $400 \mathrm{lbs}$ の荷重を 加える）を継続して与えた後圧縮歪を測定する方法で、 一定荷重としてはバネによる圧縮装置が用いられる。他． の一つは一定変形、例えば試片の硬度により20４％％の， 圧縮を加えた後圧縮歪を測定する方法で、厚みを調整す る間隔片を介して 2 枚又はそれ以上の圧縮板の間に試片 を挾み圧縮変形を与える。ASTM では $70^{\circ} \mathrm{C}, 22$ 持間 荷重をかけ放置するが、この条件は可成り苦酷である， が、実際の使用の場合とよく一致すると言はれている、 然し試片の変形状態が均一でなく圧面の状態に影響され、 るため、重複試験の精度はよくない。この他、ゴムを圧 縮した状態で振動を与えその減衰を測定する事により求 める方法も考えられている。13)19)

\subsection{Hysteresis $の$ 測定法}

i ) 伸長 hysteresis loop 試験 静的な hysteresis. を測定するもので、種々の抗張力試験機で得られる歪力 一歪曲線の伸長、弛緩の曲線の面積、即ちhysteresis の 面積より求める事が出来る。この伸張、弛緩を続けると hysteresis loop の面積は急速に減少し、4〜5回で最低. 值に達する。又この loop の面積は温度上昇に伴つて減 少する。一般に hysteresis loss はゴムに対すて与えら. れた仕事䁷 Aa とゴムのなした仕事量、即ち loopの 面積 Ar より求められるこれを hysteresis index $\mathrm{H}_{1}$ $=\mathrm{Ar} / \mathrm{Aa}$ で表しており、伸長、圧縮共に容易に測定出。 来る。 $\mathrm{H}_{1}$ は変形速度、履歴、最小歪によつて変化す る。 
ゴムは普通の抗張力試験機の様な変形、変形速度の条件 の下で応用される事は少いから hyrteresis の試験にこ の様な静的な方法を用いるのは危険である。事実 R-SG 天然ゴムの hysteresis loop の測定でも歪により大きい 差がある事が認められている。15)

ii）衝撃試験による方法これは自由に落下する球 等をゴム試片に打ち当て反撥されるエネルギー成分を测 定する方法で可成り多く用いられている。20)垂直落下距 離 $\mathrm{y}_{1}$ の時、衝撃反撥率は $\mathrm{y}_{1} / \mathrm{y}_{0}$, 衝撃 hysteresis loos $\mathrm{H}^{2}=1-\mathrm{y}_{1} / \mathrm{y}_{0}$ で与えられる。球の大きさ、形状によつ て可成り異つた果結が得られる。

衝揧による場合にも繰り返し衝撃を加えると hysteresis は減少し、従つて反撥力は增大、3〜4回で定常值 に達するる。然し予め激しく試片を屈曲、又は変形させ て後衝揧を与えてもこの様な結果はみられず、試片の同 一点に反復衝撃を与えた場合とは異る事が示される。高 温での反撥性も可成り容易に測定出来る。衝揧侙体によ る方法は極めて簡単且つ用速に行う事が出来るため合成 ゴム等にも多く用いられる。然し衡揧反撥率は内部摩 $\eta$ :擦動的弾性係数 $\mathrm{E}$ の函数であり、例えば金属円柱Mを高 さ $\mathrm{h}_{1}$ より円柱状のゴム（高さy）の表面にA 落下させ た場合、反撥された高さ $\mathrm{h}_{2}$ とすると $\left(\mathrm{h}_{2}>\mathrm{y}\right.$ とする) 術 撃反撥率は次の式で与えられる。但し $\mathrm{q}=\mathrm{y} / \mathrm{A}$ である。

$$
\mathrm{R}=\frac{\mathrm{h}_{2}}{\mathrm{~h}_{1}}=\mathrm{e}^{-\pi \eta / \sqrt{ } \mathrm{qME}}
$$

上式の様に $\mathrm{R}$ は内部摩擦 $\eta$ と弾性係数 $\mathrm{E}$ により変化 するが大抵の場合 $\eta$ が大きく作用する。然し分子棈造、

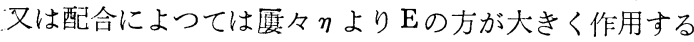
場合もあり、 $\mathrm{R}$ は内部摩擦より寧ろ弾性係数、硬度によ つて変化する事になる。

iii）自由振動による測定方法 Hysteresis の測定 に自由減衰振動を用いる方法は広く用いられている。最 も簡単な方法は撚り振子を用いたもので、ゴム仼片に撚 り変形を与えて後減変振動を起させるものである。この 時の反撥率 R'は

$$
\begin{aligned}
\mathrm{R}^{\prime} & =\left(\theta_{2} / \theta_{1}\right)^{2}=\left(\theta_{3} / \theta_{2}\right)^{2}=\cdots \cdots \\
& =\mathrm{e}^{-\pi_{\mathrm{p}_{0}} \eta / \mathrm{G}}=\mathrm{e}^{-2 \pi \eta / \sqrt{\mathrm{q}^{\prime} \mathrm{IG}}}
\end{aligned}
$$

ここに $\mathrm{p}_{0}=\sqrt{ } \mathrm{G} / \mathrm{Iq}^{\prime}$ は振動数、G は竞断弾性係数、 I は慣性能率、 $\mathrm{q}^{\prime}$ は試片によつて決る常数、 $\theta_{1}, \theta_{2}, \cdots$ は角振巾である。この様に反撥率は振動数には殆んど関 係せず、 $\mathrm{P}_{0} \eta, \mathrm{G}$ が変数と考えられる。ここに

$$
\eta=\frac{\mathrm{q}^{\prime} \mathrm{I} \mathrm{p}_{0}}{\pi} l_{\mathrm{n}}-\frac{\theta_{\mathrm{n}}}{\theta_{\mathrm{n}+1}}
$$

Yerzley oscillograph21) も減衰自由振動を行はせ、 その固有振動数と慣性モーメントより動的弾性係数、振 巾の減少比から Yerzley resilience を求めるものであ る。

自由振動法では衙揧法より測定容易であるが、振巾の 正確な自記記録が必要であり、又一般に配合等の変化に より振動数も同一でなく、決して解析は簡単とは言えな い。剪断弾性係数 $\mathrm{G}$ 女異り、叉 $\eta$ は同一振動数で比較 せ姷り絶対的な意味の少い欠点もある。高振動数の強 制振動に比し 自由振動では $\mathrm{p}_{0} \eta$ が一定の関係が成立せ ず、又自由振動での $\eta$ の值は解釈が難しい。更に $\eta, \mathrm{G}$ の 振巾に伴う変化が厚々大きい誤りを生じ易い事も考えら
れ、一般にクが可成り小さい場合は自由振動法の結果は 可成り正確であるが、GR-S の場合の様に $\eta$ が大きくな ると䛊りを生じ易くなる。

iv）共振法による測定功 $\mathrm{s}$ ，質量 Mのゴム 斌片に充分大きい集中荷重を加え、 $\mathrm{s} \approx \mathrm{Mp}_{0}{ }^{2}\left(\mathrm{p}_{0}\right.$ は自然 振動数）になる様に週期的な強制力 F cospt を加え共振 曲線を描か女、その共振点の解析によつて hysteresis loss を求める方法である共振振巾は $\mathrm{x}_{0}=\mathrm{F} / \mathrm{p}_{0} \mathrm{~b}$ (b は (1.8) 式の速度項の常数)で、 $\mathrm{s}$ は弾性係数、 $\mathrm{b}$ は摩擦係 数に関係する值である。

共振法による装置は極めて多いが、正弦的な負荷力の 与え方によつて機械的な方法、電気的に強制力を与える 万法の 2 種に大別される。

第 7 図は機械的に共振させるもので質量 $\mathrm{m}$ を争速度 $\mathrm{p}$

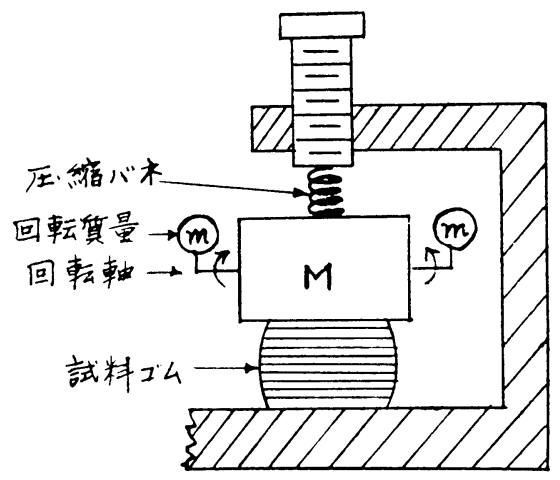

第 7 図 Kosten 式共振装䍜

で回転させる。10２2）回転軸に対してある距離だけ離れ て 2 組の互いに逆方问に回転する質量 $\mathrm{m}$ があり、互いに 水平力を打ち消しあい上下方问の加振力を生ずる。加振 垂直力成分は $4 \mathrm{mp}^{2} \mathrm{rcospt}$ ( $\mathrm{r}$ は質量の軸よりの距離)。

试片はバネで一定の静圧縮荷重Mを加えている。 M及 び振動数を変化させて共振点を求める。損失角 $\delta$ は

$$
\tan \delta=\mathrm{p}_{0} \mathrm{~b} / \mathrm{s}=\mathrm{p}_{0} \eta / \mathrm{E}
$$

で表され、振動数には殆えど無関係となる。この様な装 置では一定佰重、一定振巾の変形を得たい場合は不便で あるため、殊に合成ゴムに対しては不適当である。

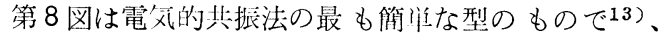

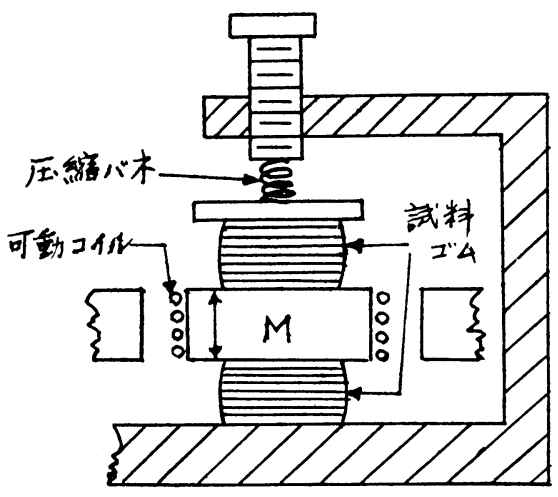

第 8 図 Naunton-Waring 式共振装置 
質量 $\mathbf{M}$ に巻かれたコイルに真空管発振器を取り付けたも

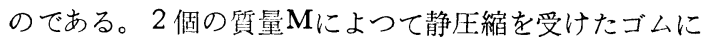
対し圧縮振動を加える。第 9 図のGoodyear 共振器はこ

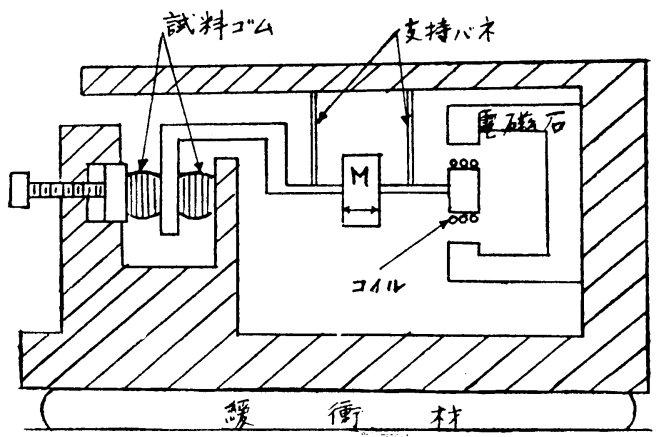

第9図 Goodyear 共振器

の種の装置を改良したものである。14)23)これはNaunton-Waring の装罡と同様圧縮振動を用いており、一定 の静荷重を加えている。振巾は直接ガラス空より読み、 強制力はコイルに通ずる電流より求め、荷重と電流の関 係は直流により補正する。6 0 cycles/sec で質星 $\mathbf{M}$ を変 化させ共振条件より $\mathrm{E}, \eta$ を求める事が出来る。即ち

$$
\mathrm{E}=\mathrm{Mq} \mathrm{p}{ }_{0}^{2}, \quad \eta=\mathrm{qF} / \mathrm{p}_{0} \mathrm{x}
$$

動的反撥率 $\quad \mathrm{R}=\mathrm{e}^{-2 \pi \mathrm{P} 0 \eta / \mathrm{E}}$

$$
\text { 熱発生量 } \quad \mathrm{H}=\frac{\pi \mathrm{p} \eta \mathrm{x}^{2}}{\mathrm{q}}=\frac{\pi \mathrm{qp} \eta \mathrm{F}^{2}}{\left(\mathrm{E}-\mathrm{Mqp}^{2}\right)^{2}+\mathrm{p}^{2} \eta^{2}}
$$

この装置では変数 $\eta, \mathrm{E}$ は振動数に殆んど関係せず11) $\eta, \mathrm{E}$ の值は試片の形状、静的な変形によつ汏る。 $\eta, \mathrm{E}$ は 共に振巾に伴い増大するが、同一の振巾、振動数では hysteresis を充分比較する事が出来、殆に高温度での測 定にも適用出来る特徴がある。14)

第10図は Firestone 共振器であるが Goodyear の装 置と同様のもので、ゴム㖪片に剪断振動を与える。24)试

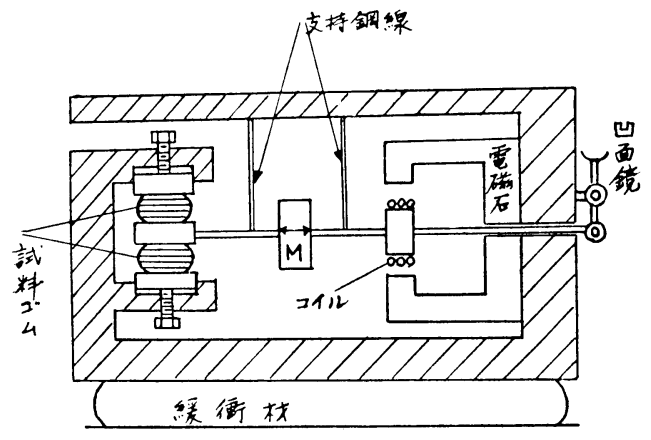

第10図 Firstone 共振器

片は望断方向に垂直に静庄縮を受ける。この装置では恒 温槽に試片を置き、温度調整をする事が出来る。60 cy cles/secでの共振条件で比較され、 $\eta, \mathrm{G}$ は次の微分方程 式より求まる。

$$
\frac{\mathrm{y}}{\mathrm{A}} \mathrm{M} \frac{\mathrm{d}^{2} \mathrm{e}}{\mathrm{dt}^{2}}+\eta \frac{\mathrm{de}}{\mathrm{dt}}+\mathrm{Ge}=\sigma \operatorname{cospt}
$$

$\sigma$ は試片に加えられる最大塑断荷重、 $\mathrm{e}$ は禀断歪、 $\mathrm{A}$

は培断面積、 $\mathrm{y}$ は試片の厚みである。この方程式の解 は、最大朔断歪 $\mathrm{e}_{\max }$ は

$$
\mathrm{e}_{\max }=\frac{\sigma}{\left(\mathrm{G}-\mathrm{y}_{\mathrm{A}} \mathrm{Mp}^{2}\right)^{2}+\mathrm{p}^{2} \eta^{2}}
$$

共振では $\quad \mathrm{e}_{0}=\sigma / \mathrm{p}_{0} \eta \mathrm{G}=\stackrel{\mathrm{A}}{\mathrm{A}} \mathrm{Mp}_{0}$

単位体積当りの発熱量は

$$
\mathrm{H} \sigma^{\prime}=\frac{\pi \mathrm{p} \eta \sigma^{2}}{\left(\mathrm{G}-\mathrm{y} \mathrm{Mp}^{2}\right)^{2}+\mathrm{p}^{2} \eta^{2}}
$$

共振では $\quad \mathrm{H}_{0}^{\prime}=\frac{\pi \sigma^{2}}{\mathrm{p}_{0} \eta}=\pi \mathrm{p}_{0} \eta \mathrm{e}_{0}^{2}$

$\mathrm{G}$ は動的突断弾性係数、 $\eta$ は内部摩擦係数であり、静 王縮力の增加に伴い減少するが、静圧縮の一定の場合は 試片の形状、大きさには無関係である。この事は種々の 形状の試料について広範囲の共振振動数が得られる利点 ともなつているGoodyear 共振器と同様 $\eta, \mathrm{G}$ は振動数 温度に依存している。

この他、永久歪を加えつつ週期的に伸長荷重を加えて 行く方法も考えられているが、この方法で得られる。 hysteresis は稍大きい值を示している25)

この様な共振法による測定は解析の簡単な事、共振曲 線全体から振動遮断効果を直接知り得る等の利点がある が、いずれの場合も振動数、振巾、初期変位、温度等の 条件を考愿して測定する必要がある。

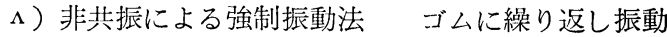
を与えると著しく発熱する。この試片の温度上昇は熱伝 導係数、輻射等による熱損失速度によつて決るが、普通 のゴム状物質では熱伝導係数は殆んど同じで、従つて温 度上昇を測定する事によつて hysteresis を測定しうる 場合が可成り多い。

Firestone flexometer の測定原理を第11図に示した

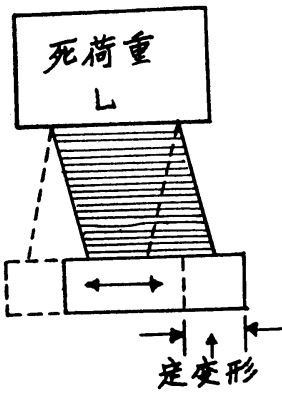

第11図 Firstone F1exometerに於ける一 定剖断変形の模式図
が、この装置では垭直な死荷 重Lを加えておき、底面を回 転させ一定振巾の总断を連続 的に加えるものである。26)変 形を継続して与えると次第に 温度は上昇し、発熱量が熱損 失と平衝になる点の温度を測 定する。然し温度上昇と共に 試片の変形も大きくなり、一 定の垂直圧縮荷重の下で嚴密 に一定䇂断振巾を与える事に なる。永久変形がないものと して初めの試片の高さ $\mathrm{y}_{1}$, 試 験後の高さ $\mathrm{y}_{2}$, 一定距離 $\mathrm{x}^{\prime}$ と すると、高さの変化は負荷面積 $\mathrm{A}_{1}$ として

$$
\mathrm{y}^{\prime}-\mathrm{y}_{2}=\mathrm{L} / \mathrm{A}_{1} \mathrm{E}_{\mathrm{st}}
$$

$\mathrm{E}_{\mathrm{st}}$ は平衝温度での圧縮に有効な弾性係数で形状に関係 する值である。 $\mathrm{e}_{\max }$ を平衝温度での最大塑断歪とする と

$$
\mathrm{x}^{\prime}=\mathrm{e}_{\max } \mathrm{y}_{2}=\mathrm{e}_{\max }\left(\mathrm{y}_{1}=\frac{\mathrm{L}}{\mathrm{A}_{1} \mathrm{E}_{\mathrm{st}}}=\right.\text { 一定 }
$$

となり flexometer は剪断荷重、振巾共に一定でない 
複雑な条件で測定されている。そvため $\mathrm{E}_{\mathrm{st}}$ の一定の場 合について比較する必要があり、hysteresis の測定に は可成り困難な方法である。

Goodrich flexometer も一定振巾を与えるものであ るが、動的な圧縮を用いている第12図に示したその装置 では試片は永久変形を受け、全荷重は一定であるが静荷 重は変化する。初期圧縮、又は初期静荷重の一定の場合 について比較する事が出来る。

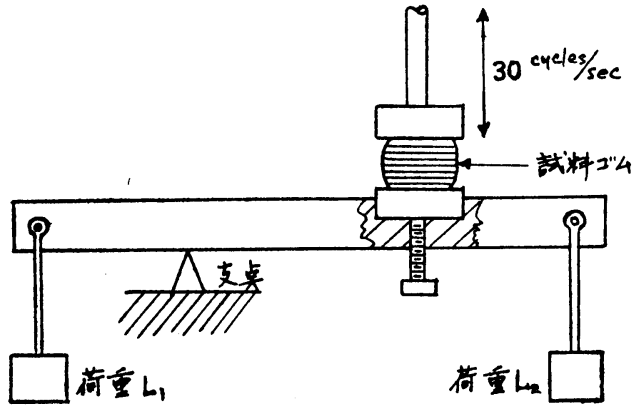

第12図 Goodrich Hexometer 模式図 （一定静荷重一定圧縮変形）

第13図の St. Joe flexometer 8) は一定の静圧縮荷 重を加え、更に水平方向の照断荷重又は変形を一えた場 合の平衝温度を測定し、相対的な $\mathrm{He}^{\prime}, \mathrm{H} \sigma$ の值を計算 する事が出来る。

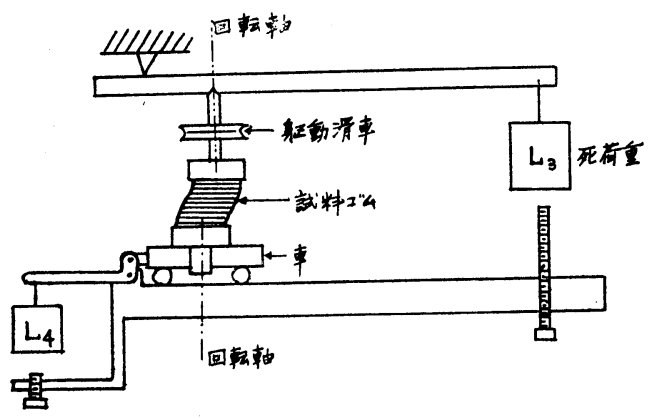

第13図 St. Joe Flexometer 模式困 (一定静荷重 : 一定息断荷重乃至変形)

第14図はRoeling の装置で27)、質量 $\mathbf{M}$ が遠心質量 mで起動され、ゴムに対し一定圧縮を与えている。A，B

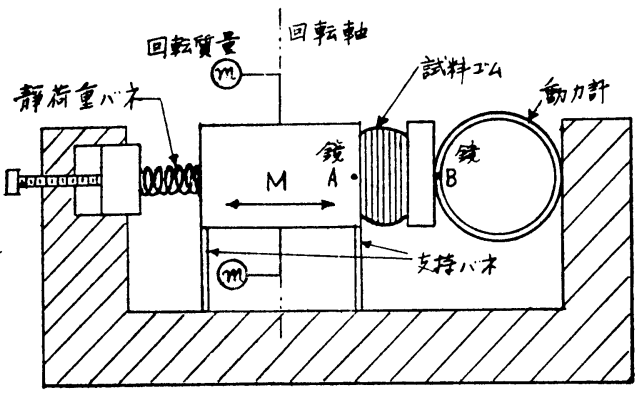

第14図 Roelig 式装置 （一定静荷重：一定動荷重）
には鏡を取り付け、双方の免の反射により動的な hysteresis loop を描かせるものである。この装置で得られ る力は系の起動力 F cos pt ではなく、ゴムに実際に与 えられる。 Roelig 荷重であるの装置で得られる loop は第 4 図とは若干異り、振動数の変化により回転する。 $\mathrm{MT}$ 式防振ゴム振動試験機もこれと同様の原理を用いた ものである。

同じ非共振の機構を用いて鹊断荷重を加いた場合に、 hysteresis loop を光電管により追跡する方法もみられ る。28)この種の装置は機構が精巧で可成り精密に測定 出来るが、loop の面積を夫々測定しなければならない 不便さがある。

第15図の Goodyear flexbmeter 女非共振を用いた 測定装置である。23) 周期的に荷重を加え温度上昇を測 定するもので一定荷重、一定変形を与える事が出来、配 合の比較にも用いられている。

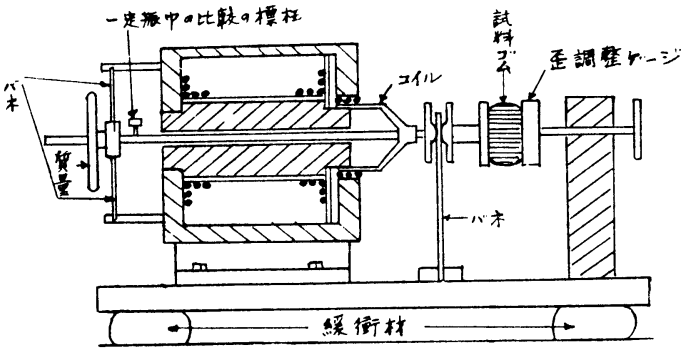

第15脑 Goodyəar Hexometer

\section{Hysteresis，永久歪に及ぼす 充填剂の影響}

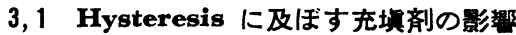

非共振法を用いて測定された Roelig の測定27)では 充填剂に Carbon Black (Fine thermal) を使用した 時、その增加に比例して hysteeresis(\%) は増加する、 Parkinson 31) は衙慗娬験法で第16四の如く同様の結果 を得ている。更にBulgin32) によると通常の配合方法 では配合量にて hysteresis は増加するが、同一量配合 したときは第17図に示す様に比表面積が増加するにつれ て hysteresis は增加する。Nauton-Harring ${ }^{33)}$ の共振 法の測定では 150cycle/sec 以上の振動数では Channel Black 配合が他のものより hysteresis は少く、Gas. Black を堌量するに伴い hysteresis は少くなることが 示されている。一般に hysteresis は gas, acetylene, lamp black の順で温度上昇と共に低下する。34) 尚 hysteresis loss は加硫度の高いもの程大きく、その変 化は最適条件附近で小さい。又硫黄及び老防の使用量は 加硫状態とは別に損失に大きく影響する。

配合物中に分散した炭素粒子の大部分がゴム分子に緊 密に結合しているとすると比較的緩速の歪力の下でも容 易に移動が起り粒子とコム、粒子間に摩擦が生ずると考 えられ、汪)この様な条件ではゴムが適当に加硫されてい るとゴム分子の可塑性は弾性に比し小さいと考えられ、 従つて内部発熱は炭素粒子に関係すると考えられる。歪 力の增加に伴い望性流動が大きく影響し静的歪力条件の. 
下で著しいことは既述の通りである。破壞点附近になる に伴い非弾性の結果として hysteresis が大となる。

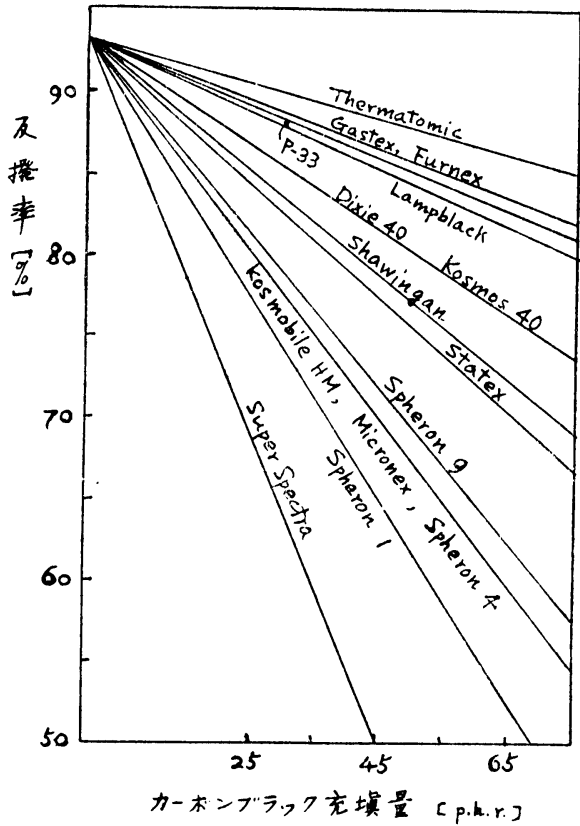

第16図 カーポンブラック充填量に対する 反撥率 $\left(50^{\circ} \mathrm{C}\right)$

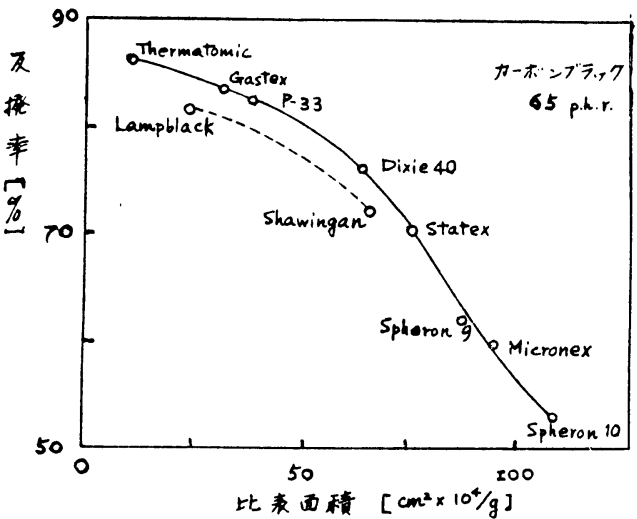

第17図比表面程に対する反撥率の関係 $\left(50^{\circ}\right)$

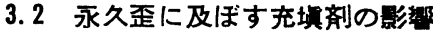

天然ゴムの種々の配含について永久歪試験の結果を第 18 図に示した。この場合は Channel 及び Thermal Black, 臼㕵、Clay, Baryte 等の充填剂を20容量用いた 配合について比較を示したものである。純ゴム配合では 永久歪は極めて小さい $(0.5 \%$ 以下)か、各試料を繰り返 し伸長したときの永久歪は相当大きらい。図に示される 様に伸長回数の增加に伴い伸長による影響は少くなる。 又第18図には一定伸長に要する荷重とその回数の関係を 示した。歪力は回数と共に減小する。これらの結果から
ゴムの軟化が起らぬ限り伸長により永久歪は殆んど増加 しないと云える。伸長により軟化の現象がみられるのは 充填剂粒子が配位に変化を生じる為と考えられる。これ は充填剂粒子の形状が問題になり殊に異方性の充填凨で
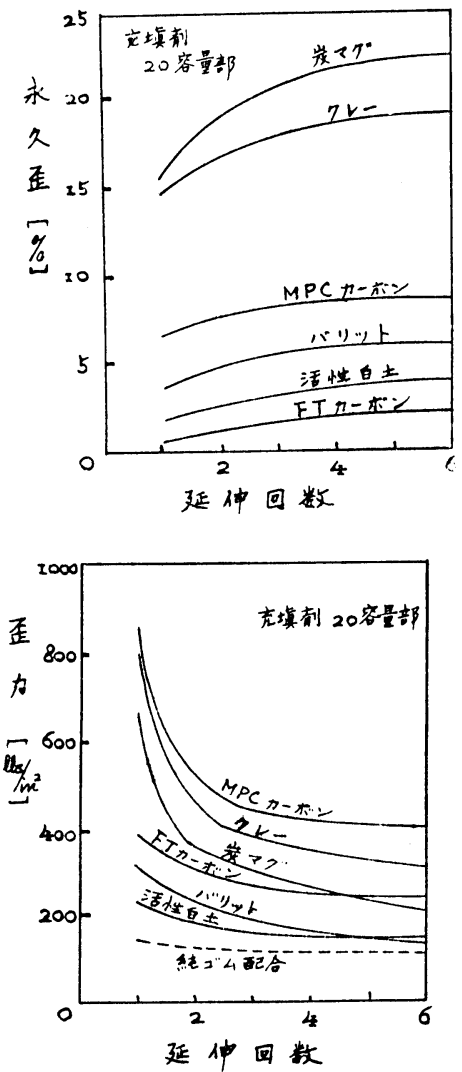

第18図 各種充填剤系の繰り返 し延伸に伴亏永久歪 (式図)、 及びかたさ右図の変化 は伸長方向に配列 されるため、永久 歪が大きく球状の ものでは小さい。 又加硫ゴムの永久 歪を左右する要素 として伸長による 容積增加がある。 伸長によりゴムと 粒子この略面が離 れて一種の空洞が 伸長方向に平行に 生ずると考えられ る。29) 電子顕微 鏡、電気的な測定 等の結果から球状 の岸素粒子では連 鎖がみられ、伸長 によりその方向に 補強性が破壞され るのが認められ従 つて小さい粒子の 炭紊程伸長による 異方性は大きく表 れる。又電子顕微 鏡で永久歪を生じ た試料では伸長時 の条痕が伸長方 向にのみみられ る $^{30}$ ことからも 充填郕粒子の配列 の異方性が考えら れる。Carbon 配 合ゴムの永久歪と Modulus の関係を第 3表に示したが この結果からこれらの間の関係を論じられないが一般的

第 3 表 Carbon 配合ゴムの永久歪

\begin{tabular}{crrrrrrr}
\hline Carbon & HMF & MPC & EPC & SRF & L.amp & MT & ET \\
\hline $300 \%$ M (psi) & 2,000 & 1,590 & 1,550 & 1,420 & 1.380 & 750 & 600 \\
$300 \%$ Set $(\%)$ & 7.5 & 7.5 & 7.0 & 4.0 & 4.0 & 2.5 & 1.0 \\
\hline
\end{tabular}

には硬度が上れば永久歪は大となり、加硫状態でも永久 歪が変化する。

\section{4. 動的、静的に対する現象の関係}

既述の如く hysteresis はその測定方法によつてその 表す意味に可成りの差がみられその結果も異つている。 静的な歪力歪曲線から hysteresis を求めることは稀で ある。これは時間的な効果が考えられておらないので意 味が少ない。

例えば室温での静的試験と動的試験をみると ${ }^{8)} 30$ 容量 の炭素配合のブチルゴムと天然ゴムについて hysteresis 
loop の価では夫々 11\%、17\%であるが反撥弾性による と反撥率が $7 \% 、 14 \%$ となり相当相違している。一般に 静的な測定による動性係数 $\mathrm{E}_{\text {stat }}$ は動的な值 $\mathrm{E}_{\mathrm{dyn}}$ より 小さく

$\mathrm{E}_{\text {dyn }} / \mathrm{E}_{\text {stat }}=1 \sim 2$

となると考えられ10)、従つて静的な条件では hysteresis は大きく表れる。この差は充填剤の添加により増大し、 最適加硫条件では小となる。これは塑性流動の効果が大 きく現れるためである。

自由振動、強制振動、反撥弾性の種々の hysteresis の 測定值を第 2 表に示したが、種々の方法で得られる $\mathrm{p} \eta$ の 絶対的な数值は一致していない。このことからも hysteresis の測定にはその測定方法の結果、意味を充分把 握しておく必要がある。

第 2 表 Hysteresis の測定値

\begin{tabular}{|c|c|c|c|c|}
\hline & \multicolumn{2}{|c|}{ 測定温度 $50^{\circ} \mathrm{C}$} & \multicolumn{2}{|c|}{ 测定温度 $100^{\circ} \mathrm{C}$} \\
\hline & $\mathrm{G} \times 106$ & $\mathrm{p} \eta \times 106$ & $G \times 106$ & $\mathrm{p} \eta \times 106$ \\
\hline & $\begin{array}{l}\text { 倠制 息由 } \\
\text { 動動 }\end{array}$ & 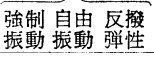 & 俍制 身 & 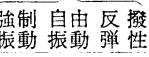 \\
\hline $\begin{array}{c}\text { 天然ゴム純ゴ } \\
\text { トレッ, } \\
\text { GR-S 純ゴ } \\
\text { トレッ, }\end{array}$ & 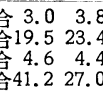 & $\begin{array}{l}2.080 .565 \\
24.20 .9 \\
2.581 .9 \\
21.828 .0\end{array}$ & $\begin{array}{rrr}0.31 & 4.7 \\
16.11 & 9.0 \\
3.9 & 6.0 \\
19.3 & 18.8\end{array}$ & 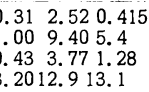 \\
\hline
\end{tabular}

\section{5. プラスチックスとゴムとの関係}

ゴムとプラスチックスでは動力学的な性質を若干異に し、例えば一般にプラスチックスは永久歪、hysteresis が大きいがこれは塑性流動の寄与によると考えられる。

Bartenev は非結晶部をもつ線状高分子について考察 しており、38ｉ）加硫ゴムの様に三次元的網目状構造を 有するもの、及び ii) polyisobutylene の様にこの様 な構造をもた如のにけている。i）では化学的分解 温度以下では望性流動を示さぬのに反し ii）ではこの現 象がみられ、この両者では殊に高温部で機械的性質を著 しく異にしている。更に力学的模式図を仮定すると第19 図の如くなりこの模式により解析が可能である。

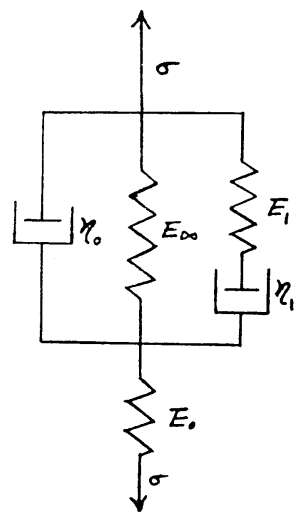

(1) 加硫ゴムの模式四

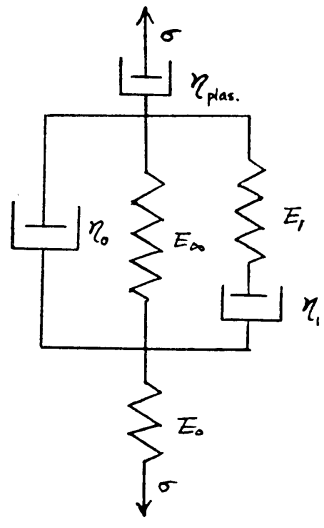

(2) ポリイソブタレンンロ模式因
第19困 Bartenev の重合物模式困

i ) では $\epsilon=\epsilon$ elas $+\epsilon$ h.elas

ii ) では $\epsilon=\epsilon$ elas $+\epsilon \cdot$ helas $+\epsilon$ plas $\epsilon$ plas は変形の弾性に基く成分、 $\epsilon \mathrm{h} \cdot$ elas は高弾性に基く 成分、 $\epsilon$ plas は塑性に基く成分である。

高分子物質は高弾性状態で変形させた場合荷重を加え ても直ちに変形を生ぜずCreep が認められる。i）では 一定時間後、一定の平衡変形に達するが ii) では Creep 現象より望性流動が優先する。この様な現象を解䣋する ために高分子物質の構造が影響する。加硫ゴムの様な網 目状棈造では強い第一次結合の他に第二次結合が存在す るため、Segment の远りは困難となり、segment の再 配列は若干後れる。一方望性流動する ii) では第二次結 合は殆んどみられず segment の再配列は早く起ると考 えられる。

山口氏39) は更に広範囲の分類を行い micelle 棈造 に着目し次の様に分類している。

i) 球状ミセル(硬化性 樹脂…石炭酸樹脂等 非硬化性樹脂....天然樹状等

i i ) 線脂ミセル……P. V.C.、ポリエチレン等

iii) 総状ミセル……ゴムセルローズ等

球状ミセルでは化学的な強い第一次絬合の他に極性基 による第二次結合によつて相互に強く凝集した榄造をも つている。この場合外力を加えたとき真流動を示し温度 の上昇と共に流動限界も低下し、このため永久歪も極め て大きく、時には全く四復しない状態になる。従つて hysteresis も著しく大きい。線状ミセルでは線状の長鎖 分子が互いに絡みつ合た棈造で分子間の第二次結合は比 較的弱い。この種のものでは高埧部でも悬流動をするこ とがなく準流動し球状ミセルの場合とは明らかに望性特 性に差がみられる。従つてその変形は殊に低温部で可成 り弾性的な要絭が多くなり、永久歪、hysteresis も球状 ミセル程大きくはない。これは分子の絡み合いのために 個々の分子流動が妨げられ、従つて真流動としての層流 が現れないためと思われる。総状ミセルでは長鎖の分子 閒の第二絬合が強く、絡み合いの外にある部分では束状 に強く結びついた総状の構造をとつている。この様なも のでは高弾性物質として知られるもので弾性限界が著し く大きく高温部でも真流動をしない。弾性限界が大きい ことは長鎖分子が比較的自由に運動出来エントロピー弾 性により解䣋出来る。この様な物質では永久歪、 hysteresis も小さく、殊に天然ゴムの純ゴム配合では他のプ ラスチックに比して著しく小さい。又総状ミセルでは結 晶化する傾问がみられるが絬晶化では望性流動を減少す る。

\section{6. 総}

括

ゴム、プラスチックスの椂な非完全弾性体について永 歪、hysteresis, heat build up, creep 等の現象を考 察した絬果、これらの現象は外力による物質の分子構 造に於ける変化即ち一次又は二次結合の破壊でなく、 segment の運動によると考え、これらの運動が塑性流 動と弾性変形の組合としての現象であると云える。この 考の下に望性流動、弾性変形について考察したものであ る。更にこれらの測定法について種々検討を加え各々の 特長を明らかにした。又ゴム、プラスチックス等の性質 とこれらの関係について考察し、種々の充填剂の影響に 
ついてこの効果を明らかにし、ヌゴム、プラスチックスの 相互の分子構造の相違についてその永久歪、 hysteresis

\section{引用}

1) L. R. G. Treloar : Trans. Faraday Soc., 36538 (1940)

Chem. Abst., 345311 (1940)

2) R.D. Andrew, A. V. Tobolsky, E. E. Hauson: J. Appl. Phys. 17352 (1946)

3) S.D.Gehman : J. Appl. Phys, 19456 (1948),

Rubber. Chem. Tech., 22105 (1949)

4) L.Mullins : India Rubber World, 12063 (1949)

Rubber Chem. Tech. 221036 (1949)

5) J. Clouaire : Rev. gén. caouchouc 2685 (1949)

Rubber Chem. Tech 22100 (1949)

6) . J.Alf rey, Jr. : "Mechanical Beharior of Hight Polymers" p. 200 (1948)

7) 䆓井, 鈴木：高分子化学 10142 (1953)

8) J. H.Dillon, S.D. Gehman : India Rubber World, 11561

(1946)' Rubber Chem. Tech. 20 827(1947)

9）椹木，菅井：材料誈験 3317 (1954)

関口：高分子 6392 (1957)

10) C. W. Koston : Proc. Rubber Tech.Conf. 1938 p. 987

11) S.D. Gehman, D.E. Woodford, R. B. Stambough: Ind. Eng. Chem., 331032 (1941)

12) P. Kainradl, F. Händler : Kaut.u.Gummi, 7 WT 1,34 (1954) Rubber Chem.Tech., 29153 (1955)

13) W. J.S. Naunton, J. R. S. Waring: Proc. Rubber Tech. Conf. 1938 p. 805

14) R. B. Stambaugh : Ind. Eng. Chem., 341385 (1942)

15) H.A. Braendle, W. B. Wiegand : J. Appl. Phys., 15 303(1944)

Rubber Chem. Tech., 17632 (1944)

16）富久，越智，古市：材料試験 6290 (1957)

17) ASTM D 412-36 T; DVM 規格 76号等

18) ASTM D, 395-55, D 395-37, T, D 395-52 T
に及ぼす作用を明らかにし前述の塑性流動と弾性変形の 現象からこれを考察したものである。
文献
19) H. Roelig: Proc. Rubber Tech. Conf. 1938 p 821 Rubber Chem. Tech., 12394 (1939)
20) ASTM D $1054-55$
21) ASTM D 945-52
22) S.D. Gehman: J. Appl. Phys., 13402 (1942)
23) S. D. Gehman, P. J. Jones, D. E. Woodford : Ind. Eng. Chem. 35964 (1934), Rubber Chem. Tech., 1776 (1944)
24) J.H.Dillon, I. B. Prettyman, G. L. Hall : J. Appl. Phys. 15 309 (1944), Rubber Chem. Tech., 17597 (1944)
25) S. Oberto, G. Palandri : Rubber Age, 63725 (1948), Rubber Chem. Tech., 221009 (1949)
26) L.V.Cooper: Ind.Eng.Chem., Anal.Ed. 5350 (1933)
27) H. Roelig : Proc. Rubber Tech. Conf., 193 p.821, Rubber Chem. Tech., 12395 (1938)
28) W.P. Fletcher, A.N. Gent : Rubber Chem. Tech., 26131 (1954)
29) H.F. Schippel : Ind. Eng, .Chem., 1233 (1920)
30) 水渡, 党川, 長谷川, 古沢：ゴム協 30251 (1957)
31) D. Parkinson : Trans. Inst. Rubber Ind., 19131 (1943)
32) D. Bulgin : ibid, 2024 (1944)
33) W. J. S. Naunton, J. R. S. Waring : ibid, 14340 (1949)
34) A. B. D. Cassie, M. Jones, W. J. S. Naunton : ibid, 1249 (1936)
35) D. Parkinson:" Advances in Colloid Science" Vol. 7 p. 426 (1946)
36) Convor: Ind. Eng. Chem., 22871 (1930)
37) H. Barron, F. H. Cotton: Trans. Inst. Rubber Ind. 7209 (1931)
38) G. M. Bartener : Rubber Ghem. Tech., 2866 (1955)
39）山口：塑性変形の理論と応用 p. 182 (1951)

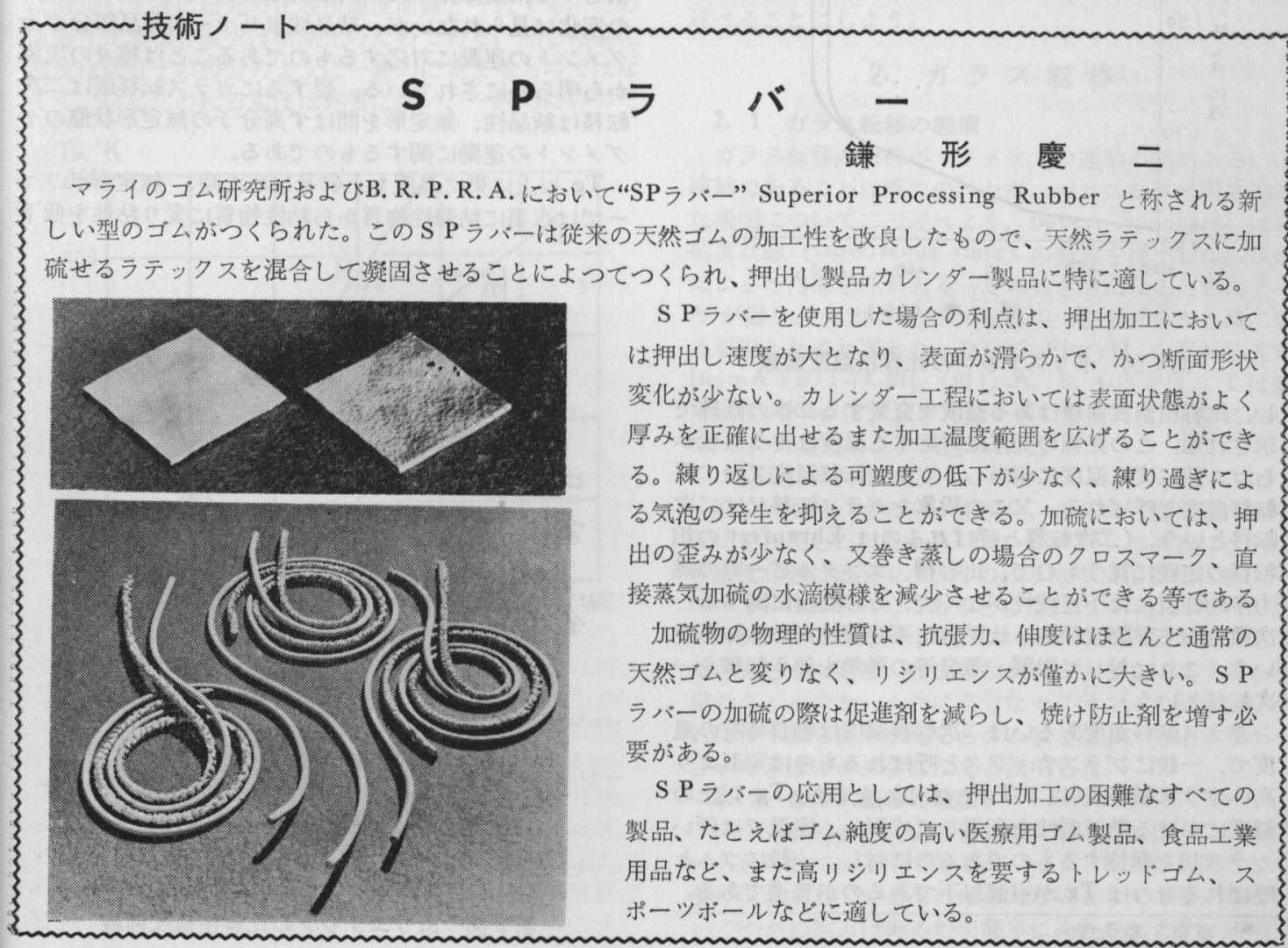

